\title{
Effect of Osmotic Stress on Sugarcane (Saccharum officinarum L.) Growth and Physiology
}

\author{
Chandrashekhar Pote ${ }^{1}$, Pankaj S. Chougule ${ }^{1 *}$ and Anil A. Kale ${ }^{2}$ \\ ${ }^{1}$ Department of Biochemistry, Post Graduate Institute, ${ }^{2}$ State Level Biotechnology Center, \\ Mahatma Phule Krishi Vidyapeeth, Rahuri, Maharashtra, India \\ *Corresponding author
}

\begin{tabular}{l} 
Ke y w o r d s \\
$\begin{array}{l}\text { Osmotic stress, } \\
\text { Sugarcane, Growth, } \\
\text { Physiology }\end{array}$ \\
Article Info \\
$\begin{array}{l}\text { Accepted: } \\
12 \text { November } 2019 \\
\text { Available Online: } \\
\text { 10 December } 2019\end{array}$ \\
\hline
\end{tabular}

A B S T R A C T
The this study two cultivars of sugarcane viz., MS-10001 and CoC-671, were evaluated for determination of salinity tolerance at different stress level as compared to control. The salinity tolerance was evaluated by determination of leaf area, shoot height, root length, chlorophyll content, chlorophyll stability index, membrane injury index. The sugarcane salinity tolerant cultivar MS-10001 showed less per cent decrease in leaf area at salt stress $(0,2,4,8 \mathrm{dSm}-1)$, it showed less per cent decrease in shoot length and root length as compared to sensitive cultivar CoC-671. The RWC was also recorded higher in sugarcane variety MS10001 at salt stress condition as compared to CoC671 at different salt stress level. Chlorophyll a, b, and total chlorophyll content reduced at stress level but found higher in MS10001 than the CoC-671 at both salt stress level. Chlorophyll stability index was more in MS10001 at different salt stress level compared to CoC671.

\section{Introduction}

Sugarcane (Saccharum officinarum L.) is a major sugar producing plant. It is also a high biomass producer and consumes large amounts of water and nutrients from the soil for achieving maximum productivity. Sugarcane is a glycophyte; reported to be salt sensitive; and exhibits toxicity symptoms, low sprout emergence, nutritional imbalance, and overall growth reduction leading to low biomass (Wahid, 2004). Brazil rank first in sugarcane production around the world followed by India and China. In India Uttar Pradesh rank first in sugarcane production followed by Maharashtra and Karnataka. In Maharashtra state Kolhapur rank first in sugarcane production (14\%) followed by 
Ahmednagar (13.40 \%) and Pune (12.54 \%) during 2012-2013.

Abiotic stress such as high salinity, drought extreme temperature are major cause of crop loss worldwide, reducing average yields for most of the crop plants by more than $50 \%$. In particular, salinity is one of the most serious threats to crop production (Pagariya et al., 2012). It is becoming an increasingly global problem and affects approximately $20 \%$ of global irrigated agricultural land (Ouyang et al., 2007).

In India out of the 9.38 million ha of salt affected soil, 3.88 million ha are alkali soil and 5.5 million ha (including coastal lands) are saline soil, while every year more and more land becomes non-productive due to salt accumulation (Jaleel et al., 2008). Salinity affects numerous physiological or biochemical process.

Many at the cellular level and induce oxidative stress in plants. Primarily, it leads osmotic stress due to decreases of soil water potential. Secondarily salinity causes the tissue accumulation of $\mathrm{Na}, \mathrm{Cl}$ and inhibition of mineral nutrients uptake causing ionic imbalance.

\section{Materials and Methods}

\section{Planting material and stress treatment}

The planting material of two sugarcane cultivars, MS-10001 a salinity tolerant and CoC-671 a salinity sensitive were obtained from Central Sugarcane Research Station, Padegaon, Dist. Satara. The sets were planted in a plastic pots containing black soil in three replicates for each treatment and grown in the control conditions in green house. After 60 days after planting the stress treatment was imposed with $\mathrm{NaCl}$ solution of concentration $0,2,4,8 \mathrm{dSm}^{-1}$.

\section{Physiological growth parameters}

The growth of the plants under stress treatment was monitored by taking the physiological characters observations after 3 days of the stress treatment. Leaf area was measured by Li-COR portable leaf area meter of every leaf of the plants.

The plant height was measured by using centimeter scale and the observations were recorded. The root length was measured by uprooting the plants by submerging pots in water so that the roots will not damage during uprooting, by using the centimeter scale the root length was measured from root crown to root tip.

\section{Relative water content (RWC \%)}

Relative leaf water content was estimated by the method described by Henderson and Davies-Jr. (1990). The third leaf from the top of the main stem was detached from 5 randomly selected plants and kept in sealable plastic bag in an ice box.

The leaf samples were brought to a laboratory where fresh weight was recorded immediately. The leaf samples were then immediately hydrated to full turgidity for 2 hours by floating on de-ionized water in a close petridish under room temperature. After 2 hours the samples were taken out of water and were well dried with a filter paper.

They were immediately weighted to obtain fully turgid weight. Samples were then dried at $80^{\circ} \mathrm{C}$ for $36 \mathrm{~h}$ and dry weight was determined. The RWC was calculated by using the following formula.

Relative Water Content $(\%)=$

Fresh Weight (g)-Dry Weight (g)

Turgid Weight (g)- Dry Weight (g) 
Membrane thermostability or membrane injury (MII \%)

Membrane thermostability was evaluated as described by Sullivan and Ross (1979). Young and fully expanded $3^{\text {rd }}$ leaf from each pot were collected. Twenty leaf discs of $0.5 \mathrm{~cm}$ diameter were punched from each sample. The discs were washed four times with distilled water in test tubes to remove exogenous electrolytes and electrolytes released from cut cells at the periphery of the discs. The excess water was removed from the tubes and the tubes were covered with plastic film. One set discs were then incubated for $15 \mathrm{~min}$ at $56+{ }^{\circ} \mathrm{C}$ in a temperature controlled water bath while the other set was maintained at room temperature (control). The incubated tubes were quickly cooled to room temperatures before adding distilled water to both sets of tubes. The tubes were then placed in an incubator for $18 \mathrm{~h}$ at $10{ }^{\circ} \mathrm{C}$ to allow leakage of electrolytes from the discs. The tubes were then brought back to room temperature, inverted several times to mix the contents and an initial measurement of electrolyte conductance was recorded using an electrical conductivity meter (CM 180, ELICO, India), after which the tubes were covered with aluminum foil and put in water bath at $100^{\circ} \mathrm{C}$ for $10 \mathrm{~min}$ to kill leaf tissues. The heated tubes were cooled to room temperature, the contents were mixed thoroughly and a second conductance was recorded. Membrane injury index \% (MI \%) was calculated as:

$M I(\%)=1-\frac{\left[1-\left(\frac{T 1}{T 2}\right)\right]}{\left[1-\left(\frac{C 1}{C 2}\right)\right]} \times 100$

\section{Total Chlorophyll content}

Total leaf chlorophyll content of Sugarcane was determined by method described by Arnon (1949). The leaf samples of sugarcane were cut into small pieces and known weight
$(0.2 \mathrm{~g})$ of fresh leaf sample was macerated in a mortar and pestle and extracted with $20 \mathrm{ml}$ of 80 percent acetone. The content were centrifuged at $5000 \mathrm{xg}$ for $10 \mathrm{~min}$ and the supernatant was collected. The final volume of extract was made to $5 \mathrm{ml}$. The extinction of chlorophyll extract was recorded at 645 and $663 \mathrm{~nm}$ on a Spectrophotometer and a blank was run with 80 per cent acetone.

The amount of total chlorophyll content was calculated by using the following formula and expressed in $\mathrm{mg} \mathrm{g}^{-1}$ fresh weight ( $\mathrm{FW}$ ).

Total Chlorophyll (mg per g FW)

V
$=20.2($ A645 $)+8.02($ A663 $) \times-------$
$1000 \times W$

Chl.A (mg per g FW)

$=12.7(\mathrm{~A} 663)-2.69(\mathrm{~A} 645) \times \frac{\mathrm{V}}{1000 \times \mathrm{W}}$

Chl.B (mg per g FW)

$=22.9(\mathrm{~A} 645)-4.68(\mathrm{~A} 663) \times \frac{\mathrm{V}}{\mathrm{-a}} \mathrm{-000 \times \textrm {W }}$

Where, $\mathrm{A}$ is absorbance at specific wave length, $\mathrm{V}$ is the final volume of chlorophyll extract in 80 per cent acetone and the $\mathrm{W}$ is the fresh weight of tissue extracted in $\mathrm{g}$.

\section{Chlorophyll stability index (CSI \%)}

The CSI was used as a measuring method to differentiate between salinity resistant and salinity susceptible variety. A laboratory method was described by Kaloyereas (1958), that determines the salinity hardiness based on the thermo-stability of chlorophyll pigments when kept in a hot water bath. The more stable the chlorophyll, the hardier the plant. CSI percentage in the leaves was estimated by using a UV spectrometer at 40 and 60 days after imposing salinity stress. Two leaf 
samples of $250 \mathrm{mg}$ each were put in two test tubes containing $10 \mathrm{ml}$ of distilled water. One of the test tubes was placed in a water bath and heated to $56 \pm 1^{\circ} \mathrm{C}$ for exactly $30 \mathrm{~min}$., while the other was kept as a control. The optical density (OD) of the extract was measured on spectrometer. Chlorophyll Stability Index (CSI) in the leaves was estimated by using following formula.

$$
\begin{aligned}
& \text { CSI (\%) } \\
& \text { Optical density (OD) value } \\
& \text { of heated sample } \\
& \text { =-------×100 } \\
& \begin{array}{l}
\text { Optical density (OD) value } \\
\text { of unheated sample }
\end{array}
\end{aligned}
$$

\section{Results and Discussion}

The leaf area of control and salt stressed of two sugarcane varieties are shown in Table 1. The stressed leaves showed decline in leaf area over unstressed control of two sugarcane varieties. The salt tolerant sugaracane variety MS-10001 found less percent decrease than salt susceptible CoC-671 variety. As stress level $\left(\mathrm{dSm}^{-1}\right)$ increased the \% leaf area was decreased in both the varieties, viz., $-4.13 \%$ $\left(2 \mathrm{dSm}^{-1}\right)-7.35 \%\left(4 \mathrm{dSm}^{-1}\right)$ and $-10.57(8$ $\left.\mathrm{dSm}^{-1}\right)$ in MS 10001 and $-6.49 \%\left(2 \mathrm{dSm}^{-1}\right)$ $6.96(4 \mathrm{dS} \mathrm{m}-1)$ and $-9.74 \%\left(8 \mathrm{dSm}^{-1}\right)$ in $\mathrm{CoC}$ 671. Saxena et al., (2010) observed considerable reduction in leaf area and biomass production in experimental ten varieties of sugarcane under saline condition as compared to the normal one. Further they reported that the reduction frequency ranged from 5.9 to $36.2 \%$ in leaf area and 2.1 to 8.9 $\%$ in biomass production indicating that these traits were adversely affected due to salinity stress. Wahid and Ghazanfar (2006) reported that the sugaracane variety HSF - 240 showed a larger leaf area under controlled condition, it presented a more consistent reduction $(71 \%)$ compared to CP-4333 (24\%) under increased salinity towards the end of the experiment.
Patade et al., (2011) noticed that the sugarcane plants treated with $150 \mathrm{mM} \mathrm{NaCl}$ for 15 days showed significant reduction in leaf width as compared to the control plants. The result obtained in the present investigation one concomitant with the earlier reports.

The shoot height of the sugarcane varieties under induced salt stress was tabulated in Table 1. It was observed that the shoot height (cm) was described with increase in salt stress $\left(\mathrm{dSm}^{-1}\right)$. However the per cent decrease was more in salt susceptible CoC 671 variety than salt tolerant MS 10001 variety. Saxena et al., (2010) reported that the reduction frequency ranged from 8.8 to $56.6 \%$ in shoot height, indicating that these traits were adversely affected due to salinity stress. It was concluded that the limiting crop growth was possibly either due to deposition of excess salts to the root zone or absorption of salts by the plants as metabolites which enhanced the osmotic potential and resulted in poor growth of plant. Patade et al., (2011) reported that the significant difference for shoot was not observed in the stressed plants as compared to the control. Growth reduction under salinity stress in terms of shoot length due to accumulation of the toxic saline ions at formative stage has been earlier reported in sugarcane by Wahid and Ghazanfar (2006). Agarwal et al., (2004) reported that the $\mathrm{NaCl}$ treatment of seedlings cassia angustifolia for 5 and 7 DAS resulted in a significant reduction in the root and shoot length. The similar trend was observed in the results obtained in the present study. The root length of control and salt stressed of two sugarcane varieties are shown in Table 1. The stressed leaves showed decline in root length over unstressed control of two sugarcane varieties. The mean root length of the variety MS-10001 was $12.75 \mathrm{~cm}$ as compared to CoC-671 was $12.53 \mathrm{~cm}$ under salt stress. Root length was decreased with advancement of the intensity of salt stress $(\mathrm{dSm}-1)$ in both the varieties. However, 
percent decrease was more in salt susceptible CoC-671 variety than the salt tolerant MS 10001 variety. Patade et al., (2011) reported that the significant difference for root lengths was not observed in the stressed plants as compared to the control. The most common salinity effect is a general stunting of plant growth. As salt concentration increases above a threshold level both the growth rate and size of most plant species progressively decrease but all the plant parts are not affected equally, however root growth is often suppressed more than that the shoot growth (Meiri and Poljakoof-Mayber, 1970). Salinity and water stress have quite similar effects on the growth and cell viability (Lutts et al., 2004). Salinity causes pronounced decrease in water uptake and plant growth in shoot and root (Misra and Dwivedi, 2004). Agarwal et al., (2004) reported that the $\mathrm{NaCl}$ treatment of seedlings for 5 and 7 DAS resulted in a significant reduction in the root and shoot length. Similar result is obtained in the present investigation.

The relative leaf water content of control and salt stressed of two sugarcane varieties are shown in Table 2. The relative leaf water content was higher in unstressed than in stressed ones in both the sugarcane varieties. The RLWC in MS10001 at $\left(0 \mathrm{dSm}^{-1}\right) 65.72 \%$

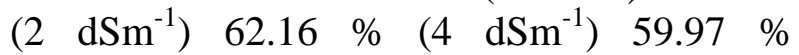
$\left(8 \mathrm{dSm}^{-1}\right) 53.38 \%$ and in variety CoC671 it was in $\left(0 \mathrm{dSm}^{-1}\right) 63.28 \%\left(2 \mathrm{dSm}^{-1}\right) 57.67 \%$ $\left(4 \mathrm{dSm}^{-1}\right) 56.93 \%\left(8 \mathrm{dSm}^{-1}\right) 45.32 \%$. Thus it was observed the reduction was more in salt susceptible CoC 671 variety than salt salt tolerant MS 10001 variety. Further, it was noticed that at $8 \mathrm{dSm}^{-1}$ salt stress the more reduction in salt susceptible $\mathrm{CoC} 671$ variety than the salt tolerant MS 10001 variety. Barrs (1968) suggested that relative water content (RLWC) under stress could also be used as a measure of tolerance to stress and could be used in varietal screening programme. Patade et al., (2011) reported that the leaf RWC was significantly low in salt $(89 \%)$ and PEG (90
$\%)$ treated plants as compared to the control (93 \%). The two sugarcane clones CP-4333 (salt tolerant) and CP-71-3002 (salt sensitive) indicated remarkable differences for relative leaf water content, which were substantially greater in CP-4333 (salt tolerant). Sinclair and Ludlow (1985) proposed that RLWC was better measure for plant's water status than thermodynamic state variables i.e. water potential, turgor potential and solute potential.

The membrane injury index of control and salt stressed of two sugarcane varieties are shown in Table 2. In the present investigation higher membrane injury was observed at all the imposed increased level of salt stress in salinity susceptible variety $\mathrm{CoC} 671$ viz., $19.57 \%$ at $0 \mathrm{dSm}^{-1}$ (control), $41.16 \%$ at 2 $\mathrm{dSm}^{-1}, 51.34$ at $4 \mathrm{dSm}^{-1}, 57.16 \%$ at $8 \mathrm{dSm}^{-}$ ${ }^{1}$ and lower was observed in salinity tolerant variety MS10001 $17.65 \%$ at $0 \mathrm{dSm}^{-1}$ (control), $34.89 \%$ at $2 \mathrm{dSm}^{-1}, 43.67 \%$ at 4 $\mathrm{dSm}^{-1}, 48.07 \%$ at $8 \mathrm{dSm}^{-1}$. The increase in the value revealed damage to the membrane is more susceptible cultivar then tolerant cultivar. Gomathi and Rakkiyapan (2011) reported that the membrane stability index was higher in Co 85004 and it was closely followed by C 92038. The Si 94050 and Co 85036 recorded lowest values in all the stages. While in control, Si 94050 recorded higher values and Co 85004 recorded lowest values in all the stages. Lower membrane stability observed in salt susceptible cultivar CoC-671 might be due to the reduction of photochemical quenching in PSII due to salt stress. Many reports have also noticed this type of pattern in different crop species. (Taishi et al., 2000; Sairam and Tyagi, 2004; Gomathi et al., 2012). Satbhai et al., (2014) studied the MSI in the leaves of two sugarcane cultivars under salt stress and observed a decreasing trend in both cultivars. However, percent reduction over control was higher in CoC-671 cultivar (29.64 \%) as against CoM$265(8.73 \%)$ a salt tolerant cultivar. 
Table.1 Effect of induced salinity stress on leaf area, shoot length and root length in salinity tolerant and salinity susceptible sugarcane varieties

\begin{tabular}{|c|c|c|c|c|c|c|c|c|c|c|c|c|}
\hline \multirow[t]{3}{*}{ Varieties } & \multicolumn{4}{|c|}{ Leaf area $\left(\mathrm{cm}^{2}\right)$} & \multicolumn{4}{|c|}{ Shoot length $(\mathrm{cm})$} & \multicolumn{4}{|c|}{ Root length $(\mathrm{cm})$} \\
\hline & \multicolumn{12}{|c|}{ Stress Level $\left(\mathrm{dS} \mathrm{m}^{-1}\right)$} \\
\hline & 0 & 2 & 4 & 8 & $\mathbf{0}$ & 2 & 4 & 8 & $\mathbf{0}$ & 2 & 4 & 8 \\
\hline \multicolumn{13}{|c|}{ Salinity Tolerant Variety } \\
\hline MS10001 & $\begin{array}{c}217.67 \\
(0)\end{array}$ & $\begin{array}{l}208.67 \\
(-4.13)\end{array}$ & $\begin{array}{l}201.67 \\
(-7.35)\end{array}$ & $\begin{array}{c}194.67 \\
(-10.57)\end{array}$ & $\begin{array}{l}130 \\
(0)\end{array}$ & $\begin{array}{c}125 \\
(-3.85)\end{array}$ & $\begin{array}{c}120 \\
(-7.69)\end{array}$ & $\begin{array}{c}115 \\
(-11.54)\end{array}$ & $\begin{array}{l}14 \\
(0)\end{array}$ & $\begin{array}{c}13.50 \\
(-3.57)\end{array}$ & $\begin{array}{c}12 \\
(-14.29)\end{array}$ & $\begin{array}{c}11.50 \\
(-17.86)\end{array}$ \\
\hline \multicolumn{13}{|c|}{ Salinity Susceptible Variety } \\
\hline CoC671 & $\begin{array}{c}215.67 \\
(0)\end{array}$ & $\begin{array}{l}201.67 \\
(-6.49)\end{array}$ & $\begin{array}{l}200.67 \\
(-6.96)\end{array}$ & $\begin{array}{l}194.67 \\
(-9.74)\end{array}$ & $\begin{array}{l}128 \\
(0)\end{array}$ & $\begin{array}{c}120 \\
(-6.25)\end{array}$ & $\begin{array}{c}119 \\
(-7.03)\end{array}$ & $\begin{array}{c}119 \\
(-11.72)\end{array}$ & $\begin{array}{c}13.50 \\
(0)\end{array}$ & $\begin{array}{c}13.30 \\
(-1.48)\end{array}$ & \begin{tabular}{|c|}
12.34 \\
$(-8.59)$
\end{tabular} & $\begin{array}{c}11 \\
(-18.52)\end{array}$ \\
\hline \multicolumn{13}{|c|}{ Interaction between varieties and treatment } \\
\hline Comparison & \multicolumn{2}{|c|}{ S.E. \pm} & \multicolumn{2}{|c|}{$\mathrm{CD}$ at $5 \%$} & \multicolumn{2}{|c|}{ S.E. \pm} & \multicolumn{2}{|c|}{$\mathrm{CD}$ at $5 \%$} & \multicolumn{2}{|c|}{ S.E. \pm} & \multicolumn{2}{|c|}{ CD at $5 \%$} \\
\hline Variety & \multirow{2}{*}{\multicolumn{2}{|c|}{$\begin{array}{l}0.385 \\
0.544\end{array}$}} & \multirow{2}{*}{\multicolumn{2}{|c|}{$\begin{array}{l}0.186 \\
1.677\end{array}$}} & \multicolumn{2}{|c|}{0.333} & \multicolumn{2}{|c|}{1.027} & \multicolumn{2}{|c|}{0.340} & \multicolumn{2}{|c|}{0.840} \\
\hline Treatments & & & & & & 471 & & .453 & 0. & 481 & & 482 \\
\hline $\begin{array}{c}\text { Variety } x \\
\text { Treatment }\end{array}$ & \multicolumn{2}{|c|}{0.770} & \multicolumn{2}{|c|}{2.372} & \multicolumn{2}{|c|}{0.667} & \multicolumn{2}{|c|}{1.820} & \multicolumn{2}{|c|}{0.680} & \multicolumn{2}{|c|}{2.625} \\
\hline
\end{tabular}

*Values in parenthesis indicates \% decrease over control

Table.2 Effect of induced salinity stress on relative leaf water content \& membrane injury index in salinity tolerant and salinity susceptible sugarcane varieties

\begin{tabular}{|c|c|c|c|c|c|c|c|c|c|}
\hline \multirow{3}{*}{$\begin{array}{l}\text { Sr. } \\
\text { No. }\end{array}$} & \multirow[t]{3}{*}{ Varieties } & Rel & ve leaf $w$ & er conte & $(\%)$ & & mbrane i & ury index & \\
\hline & & \multicolumn{8}{|c|}{ Stress Level $\left(\mathrm{dS} \mathrm{m}^{-1}\right)$} \\
\hline & & $\mathbf{0}$ & 2 & 4 & 8 & 0 & 2 & 4 & 8 \\
\hline & \multicolumn{9}{|c|}{ Salinity Tolerant Variety } \\
\hline \multirow[t]{2}{*}{1.} & MS10001 & $\begin{array}{c}65.72 \\
(0)\end{array}$ & $\begin{array}{c}62.16 \\
(-5.42)\end{array}$ & $\begin{array}{c}59.97 \\
(-8.75)\end{array}$ & $\begin{array}{c}53.38 \\
(-18.78)\end{array}$ & $\begin{array}{c}17.65 \\
(0)\end{array}$ & $\begin{array}{c}34.89 \\
(97.68)\end{array}$ & $\begin{array}{c}43.67 \\
(147.42)\end{array}$ & $\begin{array}{c}48.07 \\
(172.35)\end{array}$ \\
\hline & \multicolumn{9}{|c|}{ Salinity Susceptible Variety } \\
\hline \multirow[t]{6}{*}{2.} & CoC671 & $\begin{array}{c}63.28 \\
(0)\end{array}$ & $\begin{array}{c}57.67 \\
(-8.87)\end{array}$ & $\begin{array}{c}56.93 \\
(-10.03)\end{array}$ & $\begin{array}{c}45.32 \\
(-28.38)\end{array}$ & $\begin{array}{c}19.57 \\
(0)\end{array}$ & $\begin{array}{c}41.16 \\
(110.32)\end{array}$ & $\begin{array}{c}51.34 \\
(162.34)\end{array}$ & $\begin{array}{c}57.16 \\
(192.08)\end{array}$ \\
\hline & \multicolumn{9}{|c|}{ Interaction between varieties and treatment } \\
\hline & Comparison & \multicolumn{2}{|c|}{ S.E. \pm} & \multicolumn{2}{|c|}{$\mathrm{CD}$ at $5 \%$} & \multicolumn{2}{|c|}{ S.E. \pm} & \multicolumn{2}{|c|}{ CD at $5 \%$} \\
\hline & Variety & \multicolumn{2}{|c|}{0.008} & \multicolumn{2}{|c|}{0.026} & \multicolumn{2}{|c|}{0.224} & \multicolumn{2}{|c|}{0.691} \\
\hline & Treatments & \multicolumn{2}{|c|}{0.012} & \multicolumn{2}{|c|}{0.037} & \multicolumn{2}{|c|}{0.317} & \multicolumn{2}{|c|}{0.977} \\
\hline & $\begin{array}{c}\text { Variety x } \\
\text { Treatment }\end{array}$ & \multicolumn{2}{|c|}{0.017} & \multicolumn{2}{|c|}{0.052} & \multicolumn{2}{|c|}{0.448} & \multicolumn{2}{|c|}{1.382} \\
\hline
\end{tabular}


Table.3 Effect of induced salinity stress on chlorophyll a, chlorophyll b, total chlorophyll and chlorophyll stability index in salinity tolerant and salinity susceptible sugarcane varieties

\begin{tabular}{|c|c|c|c|c|c|c|c|c|c|c|c|c|c|c|c|c|c|}
\hline \multirow{3}{*}{$\begin{array}{c}\text { Sr. } \\
\text { No } \\
\text { • }\end{array}$} & \multirow[t]{3}{*}{ Varieties } & \multicolumn{4}{|c|}{ Chlorophyll a (mg g $\left.{ }^{-1}\right)$} & \multicolumn{4}{|c|}{ Chlorophyll b (mg g $\left.{ }^{-1}\right)$} & \multicolumn{4}{|c|}{ Total chlorophyll $\left(\mathrm{mg} \mathrm{g}^{-1}\right)$} & \multicolumn{4}{|c|}{$\begin{array}{c}\text { Chlorophyll stability index } \\
(\%)\end{array}$} \\
\hline & & \multicolumn{16}{|c|}{ Stress Level $\left(\mathrm{dS} \mathrm{m}^{-1}\right)$} \\
\hline & & $\mathbf{0}$ & 2 & 4 & 8 & $\mathbf{0}$ & 2 & 4 & 8 & $\mathbf{0}$ & 2 & 4 & 8 & $\mathbf{0}$ & 2 & 4 & 8 \\
\hline & \multicolumn{17}{|c|}{ Salinity Tolerant Variety } \\
\hline \multirow[t]{2}{*}{1.} & MS10001 & $\begin{array}{c}0.88 \\
(0)\end{array}$ & $\begin{array}{c}0.78 \\
(-11.36)\end{array}$ & $\begin{array}{c}0.75 \\
(-14.77)\end{array}$ & $\begin{array}{c}0.67 \\
(-23.86)\end{array}$ & $\begin{array}{c}1.24 \\
(0)\end{array}$ & $\begin{array}{c}1.13 \\
(-8.87)\end{array}$ & $\begin{array}{c}0.95 \\
(-23.39)\end{array}$ & $\begin{array}{c}0.87 \\
(-29.84)\end{array}$ & $\begin{array}{c}1.86 \\
(0)\end{array}$ & $\begin{array}{c}1.83 \\
(-1.61)\end{array}$ & $\begin{array}{c}1.80 \\
(-3.23)\end{array}$ & $\begin{array}{c}1.61 \\
(-13.44)\end{array}$ & $\begin{array}{l}91.64 \\
(0)\end{array}$ & $\begin{array}{l}87.36 \\
(-4.67)\end{array}$ & $\begin{array}{c}72.29 \\
(-21.12)\end{array}$ & $\begin{array}{c}67.60 \\
(-26.23)\end{array}$ \\
\hline & \multicolumn{17}{|c|}{ Salinity Susceptible Variety } \\
\hline \multirow[t]{6}{*}{2.} & CoC671 & $\begin{array}{c}0.82 \\
(0)\end{array}$ & $\begin{array}{c}0.75 \\
(-8.54)\end{array}$ & $\begin{array}{c}0.62 \\
(-24.39)\end{array}$ & $\begin{array}{c}0.44 \\
(-46.34)\end{array}$ & $\begin{array}{c}0.92 \\
(0)\end{array}$ & $\begin{array}{c}0.91 \\
(-1.09)\end{array}$ & $\begin{array}{c}0.55 \\
(-40.22)\end{array}$ & $\begin{array}{c}0.45 \\
(-51.09)\end{array}$ & $\begin{array}{c}1.80 \\
(0)\end{array}$ & $\begin{array}{c}1.53 \\
(-15.00)\end{array}$ & $\begin{array}{c}1.14 \\
(-36.67)\end{array}$ & $\begin{array}{c}0.99 \\
(-45.00)\end{array}$ & $\begin{array}{l}91.42 \\
(0)\end{array}$ & $\begin{array}{c}86.68 \\
(-5.18)\end{array}$ & $\begin{array}{c}71.17 \\
(-22.15)\end{array}$ & $\begin{array}{c}63.18 \\
(-30.89)\end{array}$ \\
\hline & \multicolumn{17}{|c|}{ Interaction between varieties and treatment } \\
\hline & Comparison & \multicolumn{2}{|c|}{ S.E. \pm} & \multicolumn{2}{|c|}{$\mathrm{CD}$ at $5 \%$} & \multicolumn{2}{|c|}{ S.E. \pm} & \multicolumn{2}{|c|}{$\mathrm{CD}$ at $5 \%$} & \multicolumn{2}{|c|}{ S.E. \pm} & \multicolumn{2}{|c|}{$\mathrm{CD}$ at $5 \%$} & \multicolumn{2}{|c|}{ S.E. \pm} & \multicolumn{2}{|c|}{ CD at $5 \%$} \\
\hline & Variety & \multicolumn{2}{|c|}{0.019} & \multicolumn{2}{|c|}{0.060} & \multicolumn{2}{|c|}{0.010} & \multicolumn{2}{|c|}{0.030} & \multicolumn{2}{|c|}{0.005} & \multicolumn{2}{|c|}{0.016} & \multicolumn{2}{|c|}{0.099} & \multicolumn{2}{|c|}{0.090} \\
\hline & Treatments & \multicolumn{2}{|c|}{0.027} & \multicolumn{2}{|c|}{0.084} & \multicolumn{2}{|c|}{0.014} & \multicolumn{2}{|c|}{0.042} & \multicolumn{2}{|c|}{0.007} & \multicolumn{2}{|c|}{0.022} & & 133 & & 410 \\
\hline & $\begin{array}{c}\text { Variety } x \\
\text { Treatment }\end{array}$ & & 039 & 0.1 & 119 & & 19 & & 060 & & 010 & & 032 & & 188 & & 580 \\
\hline
\end{tabular}

*Values in parenthesis indicates \% decrease over control 
The chlorophyll a, b and total chlorophyll content of the two sugarcane varieties MS10001 and CoC671 is shown in Table 3. The salinity tolerant sugarcane variety MS10001 had chorophyll a $0.88 \mathrm{mg} \mathrm{g}^{-1}(0$ $\left.\mathrm{dSm}^{-1}\right) 0.78 \mathrm{mg} \mathrm{g}^{-1}\left(2 \mathrm{dSm}^{-1}\right) 0.75 \mathrm{mg} \mathrm{g}^{-1}$ (4 $\left.\mathrm{dSm}^{-1}\right) 0.67 \mathrm{mg} \mathrm{g}^{-1}\left(8 \mathrm{dSm}^{-1}\right)$ and CoC $671 \mathrm{had}$ Chlorophyll a $0.82 \mathrm{mg} \mathrm{g}^{-1}\left(0 \mathrm{dS} \mathrm{m}^{-1}\right) 0.75 \mathrm{mg}$ $\mathrm{g}^{-1}\left(2 \mathrm{dSm}^{-1}\right) 0.62 \mathrm{mg} \mathrm{g}^{-1}\left(4 \mathrm{dSm}^{-1}\right) 0.44 \mathrm{mg} \mathrm{g}^{-1}$ $\left(8 \mathrm{dSm}^{-1}\right)$. Chlorophyll b content was found higher than the chlorophyll a content in both the varieties. Total chlorophyll content was also decreased with increase in salt stress conditions. In sugarcane variety MS10001, total chlorophyll was $1.86 \mathrm{mg} \mathrm{g}^{-1}\left(0 \mathrm{dSm}^{-1}\right)$ $1.83 \mathrm{mg} \mathrm{g}^{-1}\left(2 \mathrm{dSm}^{-1}\right) 1.80 \mathrm{mg} \mathrm{g}^{-1}\left(4 \mathrm{dSm}^{-1}\right)$ $1.61 \mathrm{mg} \mathrm{g}^{-1}\left(8 \mathrm{dSm}^{-1}\right)$ and $\mathrm{CoC} 671$ had as Total chlorophyll $1.80 \mathrm{mg} \mathrm{g}^{-1}\left(0 \mathrm{dSm}^{-1}\right) 1.53$ $\mathrm{mg} \mathrm{g}^{-1}\left(2 \mathrm{dSm}^{-1}\right) 1.14 \mathrm{mg} \mathrm{g}^{-1}\left(4 \mathrm{dSm}^{-1}\right) 0.99$ $\mathrm{mg} \mathrm{g}^{-1}\left(8 \mathrm{dSm}^{-1}\right)$. It was observed that per cent reduction for chlorophyll a and chlorophyll $b$ was more at $8 \mathrm{dSm}^{-1}$ salt stress followed 4 $\mathrm{dSm}^{-1}$ in salt susceptible cultivar CoC 671. However, at $2 \mathrm{dSm}^{-1}$ the reduction for chlorophyll a and chlorophyll $b$ was more in salt resistant MS 10001 cultivar but in case of total chlorophyll content the reduction was more in salt susceptible cultivar. Chlorophyll is a major constituent in cell organelle which is responsible for photosynthesis. Under saline condition, the lower values of chlorophyll content as compared to normal probably slowed down the carbohydrate metabolism and ultimate accumulation of biomass which in turn affected the crop growth. Adverse effect of salt stress on photosynthesis is well known in a number of crops (Robinson et al., 1983). Significant differences for chlorophyll contents in leaf under normal and saline condition were observed in sugarcane varieties. The rapid reduction in chlorophyll a and $b$ is reflected on the chlorophyll $a / b$ ratio and varietal as well as treatment effects were significant during the stress period. Reduction in chlorophyll concentration in response to salinity has been documented for sugarcane
(Joshi and Naik 1980, Chandra et al., 1993).The chlorophyll stability index of control and salt stressed plants of two sugarcane varieties are shown in Table 3. The stressed leaves showed decline in chlorophyll stability index over unstressed control of two sugarcane varieties. The sugarcane variety MS10001 had $91.64 \% \mathrm{CSI}$ at $0 \mathrm{dSm}^{-1}$ salt stress which decreases to $87.36 \%$ at $2 \mathrm{dSm}^{-1}$, $72.29 \%$ at $4 \mathrm{dSm}^{-1}, 67.60 \%$ at $8 \mathrm{dSm}^{-1}$. In CoC671 it was $91.42 \% \mathrm{CSI}$ at $0 \mathrm{dSm}^{-1}, 86.68$ $\%$ at $2 \mathrm{dSm}^{-1}, 71.17$ percent at $4 \mathrm{dSm}^{-1}, 63.18$ $\%$ at $8 \mathrm{dSm}^{-1}$. The salinity tolerant variety of sugarcane MS10001 has higher stability as compared to salinity susceptible variety CoC671 as revealed by per cent decrease in Chlorophyll stability index during salt stress imposition. Patade et al., (2011) reported that the salt and PEG stress treatments resulted in significant reduction in chlorophyll stability index by 10 and $40 \%$ of the control, respectively

\section{References}

Agarwal, S. and Pandey, V. 2004. Antioxidant enzyme responses to $\mathrm{NaCl}$ stress in Cassia angustifolia. Biol. Plant. 48: 555-560.

Arnon, D.L. 1949. A copper enzyme is isolated chloroplast polyphenol oxidase in Beta vulgaries. Plant Physiol. 24: 1-15.

Chandra, P., Singh, S.K., Singh, J. and Singh, S.B. 1993. Influence of salt stress on photosynthetic pigment and dry weight of sugarcane shoot culture in vitro. Cooperative Sugar 24: 611-612.

Duan, D.Y., Li, W.Q., Liu, X.J. and Ouyang, H.P. 2007. Seed germination and seedling growth of Suaeda Salsa under salt stress. Annales Botanici. Fennici. 44: 161-169.

Gomathi, R. and Rakkiyapan, P. 2011. Comparative lipid peroxidation, leaf membrane thermostabiliy and 
antioxidant system in four sugarcane genotypes differing in salt tolerance. Int. J. Plant Physiol. Biochem. 3 (4): 67-74.

Gomathi, R., Manohari, G. and Rakkiyappan, P. 2012. Antioxidant enzymes on cell membrane integrity of sugarcane varieties differing in flooding tolerance. Sugar Tech. 14 (3): 261-265.

Henderson, J.C. and Davies, Jr.F.T. 1990. Drought acclimation and the morphology of mycorrhizal Rosa hybrids L. cv. 'Ferdy' independent of leaf elemental content. New Phytol. 175: 503-510.

Jaleel, C.A., Sankar, B., Sridharan, R. and Panneerselvam, R. 2008. Soil salinity alters growth, chlorophyll content and secondary metabolite accumulation in Catharanthus roseus. Turk. J. Biol. 32: 79-83.

Joshi, G.V. and Naik, G.R. 1980. Response of sugarcane to different types of salt stress. Plant and Soil 56: 255- 263.

Kaloyereas, S.A.1958. A new method of determining drought resistance. Plant Physiol. 33 (3): 232-233.

Lutts, S., Almansouri, M. and Kinet, J.M. 2004. Salinity and water stress have contrasting effects on the relationship between growth and cell viability during and after stress exposure in durum wheat callus. Plant Sci. 167(1): 9-18.

Meiri, A. and Poljakoff-Mayber, A. 1970. Effect of various salinity regimes on growth, leaf expansion and transpiration rate of Bean plants. Soil Sci. 109: 26-34.

Misra, N. and Dwivedi, U.N. 2004. Genotypic difference in salinity tolerance of green gram cultivars. Plant Sci. 166: 11351142.

Pagariyaa, M.C., Devarumatha, R.M. and Kawara, P.G. 2012. Biochemical characterization and identification of differentially expressed candidate genes in salt stressed sugarcane. Plant Sci. 184: 1-13.

Patade, V.Y., Bhargava, S. and Suprasanna, P. 2011. Salt and drought tolerance of sugarcane under iso-osmotic salt and water stress: growth, osmolytes accumulation and antioxidant defense. J. Plant Interactions. 6(4): 275-282.

Robinson, S.P., Downton, J.W., John, D. and Millhouse, J.A. 1983. Photosynthesis and ion contact of leaves and isolated chloroplasts of salt stressed spinach. Plant Physiol 73: 238-242.

Sairam, R.K. and Tyagi, A. 2004. Physiology and molecular biology of stress tolerance in plants. Curr. Sci. 86: 407421.

Satbhai, R.D. and Naik, R.M. 2014. Osmolytes accumulation, cell membrane integrity, and antioxidant enzymes in sugarcane varieties differing in salinity tolerance. Sugar Tech. 16(1): 30-35.

Saxena, P., Srivastava, R.P. and Sharma, M.L. 2010. Studies on salinity stress tolerance in sugarcane varieties. Sugar Tech. 12(1): 59-63.

Sinclair, T.R. and Ludlow, M.M. 1985. Who taught plants thermodynamics? The unfulfilled potential of plant water potential. Aust. J. Pl. Physiol. 12 (3): 213-217.

Sullivan, C.Y. and Ross, W.M. 1979. Selecting for drought and heat resistance in grain sorghum. In $\mathrm{H}$. Musell and R. C. Staples (Eds.), Stress physiology in crop plants. Pp. 263-281.

Taishi, U., Katsuyoshi, S., Morio, K. and Takao, V. 2000. Enhancement of salt tolerance in soybean with $\mathrm{NaCl}$ pretreatment. Physiol. Plant. 110: 5963.

Wahid, A. 2004. Analysis of toxic and osmotic effects of sodium chloride on leaf growth and economic yield of 
sugarcane. Bot. Bull. Acad. Sin. 45: $133-141$.

Wahid, A. and Ghazanfar, A. 2006. Possible involvement of some secondary metabolites in salt tolerance of sugarcane. J. Plant Physiol. 163: 723730.

\section{How to cite this article:}

Chandrashekhar Pote, Pankaj S. Chougule and Anil A. Kale. 2019. Effect of Osmotic Stress on Sugarcane (Saccharum officinarum L.) Growth and Physiology. Int.J.Curr.Microbiol.App.Sci. 8(12): 1472-1481. doi: https://doi.org/10.20546/ijcmas.2019.812.176 